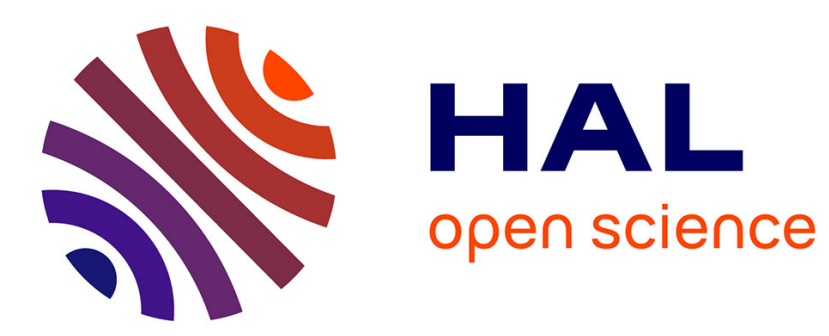

\title{
Variation for polyphenol oxidase activity in stems of Medicago species
}

\author{
Michele Bellucci, Fulvio Pupilli, Sergio Arcioni
}

\section{To cite this version:}

Michele Bellucci, Fulvio Pupilli, Sergio Arcioni. Variation for polyphenol oxidase activity in stems of Medicago species. Agronomie, 1999, 19 (1), pp.73-77. hal-00885915

\section{HAL Id: hal-00885915 https://hal.science/hal-00885915}

Submitted on 1 Jan 1999

HAL is a multi-disciplinary open access archive for the deposit and dissemination of scientific research documents, whether they are published or not. The documents may come from teaching and research institutions in France or abroad, or from public or private research centers.
L'archive ouverte pluridisciplinaire HAL, est destinée au dépôt et à la diffusion de documents scientifiques de niveau recherche, publiés ou non, émanant des établissements d'enseignement et de recherche français ou étrangers, des laboratoires publics ou privés. 


\title{
Original article
}

\section{Variation for polyphenol oxidase activity in stems of Medicago species}

\author{
Michele Bellucci, Fulvio Pupilli*, Sergio Arcioni \\ Istituto di Ricerche sul Miglioramento Genetico delle Piante Foraggere, via Madonna Alta 130, 06128, Perugia, Italy
}

(Received 7 October 1998; accepted 16 November 1998)

\begin{abstract}
Polyphenol oxidase (PPO) activity was detected in stems of both glandular-haired and glabrous wild Medicago species. Two PPO isoforms appeared in each Medicago species, the heavier isoform ranged from 120 to 180 $\mathrm{kDa}$ and the lighter one from 65 to $75 \mathrm{kDa}$. The substrate affinity for 4-methyl catechol was quite low $\left(\mathrm{K}_{\mathrm{m}}\right.$ around 0.5 $\mathrm{mM}$ ) in all the species examined. The PPO specific activity present in the stem epidermis of insect-resistant Medicago spp. was remarkably higher than that measured in the same tissue of susceptible alfalfa, thus suggesting a possible role of PPO in resistance against biotic stresses. (๑ Inra/Elsevier, Paris.)
\end{abstract}

insect resistance / Medicago spp / Leguminosae / polyphenol oxidase

Résumé - L'activité de la polyphénoloxydase (PPO) dans des tiges d'espèces de Medicago. L'activité de la polyphénoloxydase a été détectée dans des tiges d'espèces spontanées de Medicago, aussi bien du type à poils glandulaires que du type glabre. Deux isoformes de PPO sont apparues dans chacune des espèces de Medicago, la plus lourde allant de 120 à $180 \mathrm{kDa}$ et la plus légère de 65 à $75 \mathrm{kDa}$. L'affinité du substrat pour le 4-méthylcatéchol est restée sur des valeurs plutôt basses $\left(\mathrm{K}_{\mathrm{m}}\right.$ aux alentours de $\left.0,5 \mathrm{mM}\right)$ chez toutes les espèces examinées. L'activité spécifique de la PPO relevée dans l'épiderme de la tige des espèces résistantes aux insectes est apparue comme nettement plus forte que celle mesurée dans le même tissu chez la luzerne sensible, ce qui suggère que la PPO pourrait jouer un rôle dans la résistance aux stress biotiques. (@ Inra/Elsevier, Paris.)

résistance aux insectes / Medicago spp. / Leguminosae / polyphénoloxidase

\section{INTRODUCTION}

Polyphenol oxidases (PPOs) are copper enzymes that, through the reduction of molecular $\mathrm{O}_{2}$, catalyse the hydroxylation of monophenols to $o$-diphenols (cresolase activity, EC 1.14.18.1) as well as the oxidation from $o$-diphenols to $o$ quinones (catecholase activity, EC 1.10.3.2). PPOs are localised in the plastids and are widespread among the angiosperms but their biological functions have not been clearly established [22]. Generally, these enzymes are involved in the browning of fruits and tissues as a consequence of

Communicated by Michael D. Hayward (Aberystwyth, United Kingdom)

\footnotetext{
* Correspondence and reprints

E-mail: F.Pupilli@irmgpf.pg.cnr.it
} 
quinone adduct formation. For this reason they have been intensely studied in food technology [15]. Plant quinones also affect plant-pest interactions decreasing the nutritive value of plant proteins [6] and giving rise to a general toxic effect [16]. Another aspect of plant-insect resistance involving $\mathrm{PPO}$ activity concerns the $\mathrm{O}_{2}$-requiring polymerisation of the exudate of glandular trichomes in some solanaceous species, which results in entrapment of insect pests $[1,12,25]$. Antibiotic factors against insect attacks have proved to be present in the exudate of glandular trichomes of several Medicago species, and their mechanism is supposed to consist of both toxic and mechanical anti-feeding features [23]. Glandular-haired Medicago spp. expressing insect resistance are generally wild and annual, while the insect-susceptible cultivated alfalfa (Medicago sativa L.) lacks glandular trichomes.

We measured the PPO activity in stem tissues of both glandular-haired and glabrous Medicago spp. in an attempt to correlate it with insect resistance. For this purpose the wild and completely autogamous Medicago spp. M. rugosa, $M$. scutellata and $M$. intertexta, showing various degrees of resistance to the most common alfalfa insect attackers, were taken into account [23]. Since the Medicago glandular trichomes did not brake upon contact, we compared the PPO activity of the stem epidermis of glandular-haired and glabrous races of $M$. intertexta to investigate trichome-specific PPO variants at both quantitative and qualitative levels. Susceptible $M$. sativa was also used as control.

\section{MATERIALS AND METHODS}

\subsection{Plant material}

Seeds were obtained from the following sources: $M$. rugosa (SA 2202), M. scutellata (SA 18640), glabrous M. intertexta (SA 5788) were from the South Australian Department of Agriculture, Medicago Genetic Resource Centre, Adelaide, Australia and glandular-haired $M$. intertexta (242) was from the International Centre for Agriculture Researches in Dry Areas (ICARDA), Aleppo, Syria; alfalfa seeds belonged to the commercial variety 'Maremmana'. Five plants of each species were raised in the greenhouse.

\subsection{Protein extraction and PPO assay}

Epidermis was separated from stems with tweezers. Four hundred milligrams of either peeled stems or epidermis were ground in a mortar with liquid nitrogen, and the powder obtained resuspended in $500 \mu \mathrm{L}$ of extraction buffer $(50 \mathrm{mM}$ sucrose; $100 \mathrm{mM} \mathrm{NaPi}, \mathrm{pH} 7.0 ; 10 \mathrm{mM}$ cysteine) [1]. The slurry was then centrifuged $(15000 \mathrm{~g}$ for $20 \mathrm{~min}$ at $4{ }^{\circ} \mathrm{C}$ ) to pellet impurities and the supernatant was transferred to an eppendorf tube and kept on ice. Protein concentration was measured as described by Bradford [2]. PPO activity and enzymatic units were determined according to Esterbauer et al. [7] by using 10 mM 4-methyl catechol as substrate. Catalase (280 units, Sigma) was added to the assay solution to prevent oxidation of the substrate by peroxidase [22]. Change in $\mathrm{A}_{412}$ was detected in a Varian Cary spectrophotometer.

\subsection{PAGE gel staining}

Proteins were analysed by PAGE under non-reducing conditions on $7.5 \%$ polyacrylamide gels [18]. Gels were run at $25 \mathrm{~V} / \mathrm{cm}$ for $4 \mathrm{~h}$ at $5{ }^{\circ} \mathrm{C}$. After electrophoresis gel plates were stained for PPO activity in $0.1 \mathrm{M} \mathrm{NaPi}, \mathrm{pH}$ 7.0, 0.3 M 4-metyl-cathecol and $90 \mathrm{mM} p$-phenylenediamine for 5-10 min [1]. The PPO inhibitor diethyldithiocarbamate (DEDTC) was added to the staining mixture according to Sherman et al. [22]. $\mathrm{M}_{\mathrm{r}} \mathrm{s}$ were estimated by running gels of different acrylamide concentrations, from 4 to $12 \%$, and by calculating the protein mobilities as $\mathrm{R}_{\mathrm{f}}$. Proteins of known molecular weight (from $340000 \mathrm{kDa}, \alpha_{2}$-macroglobulin, to $26600 \mathrm{kDa}$, triosephosphate isomerase) were electrophoresed under these conditions and the data obtained were treated as indicated by Hedrick and Smith [8] to create a standard curve.

\section{RESULTS AND DISCUSSION}

The method developed by Esterbauer et al. [7] which depends on following spectrophotometrically the decrease in the adsorbance of the yellowcoloured 2-nitro-5-thiobenzoic acid (TNB), was used to assay PPO activity. Enzyme activity was detected in all the Medicago species examined (table $I$ ) but not in boiled extracts. PPO affinity for 4-methyl-cathecol was relatively low in epidermis of all the species investigated $\left(\mathrm{K}_{\mathrm{m}}\right.$ ca. $0.5 \mathrm{mM}$, table $I$ ). These values are in agreement with the $\mathrm{K}_{\mathrm{m}} \mathrm{s}$ reported in plants, usually around $1 \mathrm{mM}$ [16], even if higher values have also been reported [20]. Table 
I shows that PPO activity was higher in the epidermis than in peeled stems for all the species examined, but the ratio between the PPO specific activity of the epidermis and peeled stems was markedly higher in wild species (range 3.6-7.6) than in $M$. sativa (1.4). PPO specific activity present in the epidermis of insect-susceptible $M$. sativa was remarkably lower than that of all the annual resistant Medicago spp. However, PPO specific activity of the epidermis of glabrous $M$. intertexta was higher than that of its glandular-haired counterpart indicating that at least for this species, the high value of PPO specific activity of the epidermis is not necessarily correlated with the presence of glandular trichomes. Taken together, these results give a strong indication that PPO may be involved in resistance mechanisms in Medicago. On the other hand, increased level of PPO in tissues injured by insect attack has already been reported in alfalfa by Jiang and Miles [10]. Resistance to insect oviposition and larval development among annual Medicago spp. was correlated with the presence of erect glandular trichomes on the plants [5, 11, 21]. Although it was initially suggested that the viscosity of the exudate from the glandular trichomes determined larval mortality [13], it was later reported by Danielson et al. [4] that factors other than the sticky nature of the exudate may have contributed to larval mortality in resistant $M e d i c a g o$ species. The same authors suggested that morphological and anatomical characteristics conditioned resistance to oviposition and that the role of the glandular trichomes on oviposi- tion was uncertain [5]. In Solanum berthaultii the heads of glandular trichomes rupture upon insect contact discharging an exudate that rapidly undergoes oxidative polymerization and entraps insects [12]. PPO is the enzyme responsible for the oxidative polymerization and it constitutes up to $70 \%$ of the protein content of the trichomes.

Up to now, it has not been demonstrated whether insect resistance in glandular-haired Medicago species is due to the mechanical entrapment of insects in a sticky substance exuded by glandular trichomes. Our results indicate that in $M$. intertexta the presence of glandular hairs is not associated with high values of PPO specific activity. Furthermore, while attempting to collect the exudate from individual trichomes on the glandularhaired species, we realised that their bulbous head did not rupture easily upon contact as in $S$. berthaultii. This suggests that the role of glandular trichomes in insect resistance is different in the two genera.

In order to characterise further the Medicago PPO, we studied the effect of DEDTC and 2,3dimercaptopropanol (British Anti-Lewisite, BAL), which interact with the copper prosthetic group of PPO inhibiting the PPO activity [19]. Both BAL and DEDTC inhibited more efficiently the PPO of $M$. sativa than that of the other species at all the concentrations exploited (table $I I$ ). Inhibition activity of BAL was markedly greater than DEDTC, in that BAL $0.1 \mathrm{mM}$ lowered PPO activity by $63 \%$ in

Table I. PPO enzymatic activity in stem tissue of Medicago species. The values are the mean $( \pm$ se) of three independent experiments.

\begin{tabular}{lccc}
\hline Medicago spp. & $\begin{array}{c}\mathrm{Km} \\
(\mathrm{mM})\end{array}$ & \multicolumn{2}{c}{$\begin{array}{c}\text { Specific activity } \\
\text { units } \mathrm{min}^{-1} \mathrm{mg}^{-1} \text { proteins }\end{array}$} \\
\cline { 3 - 4 } & & Epidermis & Peeled stems \\
\hline M. sativa & $6.2( \pm 0.4) \times 10^{-1}$ & $0.24 \pm 0.04$ & $0.17 \pm 0.08$ \\
M. intertexta & $4.0( \pm 0.6) \times 10^{-1}$ & $2.30 \pm 0.08$ & $0.54 \pm 0.12$ \\
$M$. intertexta & $5.7( \pm 0.3) \times 10^{-1}$ & $1.55 \pm 0.07$ & $0.27 \pm 0.06$ \\
$M$. scutellata & $5.7( \pm 0.2) \times 10^{-1}$ & $0.73 \pm 0.10$ & $0.09 \pm 0.04$ \\
$M$. rugosa & $3.7( \pm 0.4) \times 10^{-1}$ & $1.47 \pm 0.06$ & $0.40 \pm 0.04$
\end{tabular}

${ }^{\mathrm{g}}$ Glabrous $M$. intertexta; ${ }^{\mathrm{h}}$ haired $M$. intertexta. 
Table II. Effect of the inhibitors BAL and DEDTC on the PPO activity in stem epidermis of Medicago species.

\begin{tabular}{|c|c|c|c|c|c|c|c|c|}
\hline \multirow[t]{3}{*}{ Medicago spp. } & \multicolumn{8}{|c|}{ PPO activity (\% of the control) } \\
\hline & \multicolumn{4}{|c|}{$\mathrm{BAL}(\mathrm{mM})$} & \multicolumn{4}{|c|}{ DEDTC $(\mathrm{mM})$} \\
\hline & 0.1 & 0.5 & 1.0 & 3.0 & 0.1 & 0.5 & 1.0 & 3.0 \\
\hline M. sativa & 37 & 24 & 18 & 15 & 100 & 57 & 41 & 34 \\
\hline M. intertextag & 86 & 47 & 40 & 33 & 100 & 72 & 61 & 55 \\
\hline M. intertexta ${ }^{\mathrm{h}}$ & 50 & 41 & 38 & 23 & 81 & 71 & 60 & 49 \\
\hline M. scutellata & 81 & 56 & 44 & 38 & 100 & 100 & 87 & 80 \\
\hline M. rugosa & 78 & 69 & 54 & 40 & 100 & 100 & 100 & 63 \\
\hline
\end{tabular}

glabrous $M$. intertexta; ${ }^{\mathrm{h}}$ haired $M$. intertexta.

M. sativa and an average of $26 \%$ in the other species, while the same concentration of DEDTC did not affect the enzymatic activity. Different results were reported in Solanum berthaultii where DEDTC was a more potent inhibitor than BAL [19]. These findings provide further evidence that i) PPO of susceptible $M$. sativa differs from that of resistant Medicago spp. and ii) Medicago PPOs differ from that contained in glandular trichomes of $S$. berthaultii.

PAGE analysis of PPO revealed two reproducible bands in all the Medicago species considered (figure 1). The $\mathrm{M}_{\mathrm{r}}$ of the heavier PPO isoform was 180 $\mathrm{kDa}$ in $M$. rugosa and $M$. scutellata, $120 \mathrm{kDa}$ in all the other species, while the $\mathrm{M}_{\mathrm{r}}$ of the lighter PPO isoform was $75 \mathrm{kDa}$ in $M$. sativa and $65 \mathrm{kDa}$ in all the other spp. In figure $1 \mathrm{M}$. scutellata shows both 180 and $120 \mathrm{kDa}$ bands but the $120 \mathrm{kDa}$ band was not reproducible. It is worth noting that, at acrylamide concentrations higher than $7.5 \%$, the two PPO isoforms appeared as a doublet or triplet (data not shown). Plant PPOs have heterogeneous $M_{r}$ values ranging from 30 to more than $200 \mathrm{kDa}$ even if the usually reported molecular weights of PPO range from 30 to $72 \mathrm{kDa}[16,17,22]$. The nature of this variation remains unclear and it is suggested that PPO isoforms could be the result of a family of genes, oxidative aggregates, protease activity and alkylation by quinones $[1,17,24]$. Recently, a number of cDNAs and genes coding for plant PPO have been isolated and characterised [3, 9]. PPO expression in plants seems to be regulated by a complex gene family that in tomato is formed by up to seven

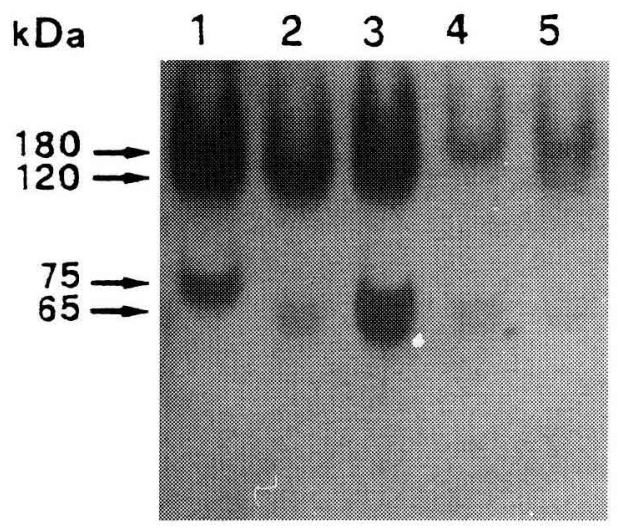

Figure 1. PPO staining of a $7.5 \%$ polyacrylamide gel. The same volume $(50 \mu \mathrm{L})$ of proteins extracted from stem epidermis of different species were loaded. Lanes 1-5: $M$. sativa, haired $M$. intertexta, glabra $M$. intertexta, $M$. rugosa, $M$. scutellata.

nuclear genes characterised by different tissue-specific regulation [17]. In the genus Nicotiana the range reported for PPO isozymes was from 47 to $120 \mathrm{kDa}$ [14]. It is possible that the $120 \mathrm{kDa}$ PPO detected in this study is a dimeric form of the 65 $\mathrm{kDa} \mathrm{PPO}$, arising from association-dissociation mechanisms [16].

In conclusion, it is out of the question that, in the Medicago species here examined, PPO was more active in the epidermis than in other stem tissues and this fact, together with the natural defensive role of epidermis, and the great differences in specific activity detected between susceptible $M$. sativa and resistant Medicago spp., support the idea that PPO is involved in the resistance to biotic 
stresses. However, qualitative differences were not detected between glabrous and glandular-haired $M$. intertexta for the PPO activity of the stem epidermis and, indeed glabrous $M$. intertexta had the highest value of PPO activity, indicating that at least for this species the anti-feeding effect of PPO may be due to the production of anti-quality factors. Further studies are necessary to screen for quantitative variation of epidermal PPO within the alfalfa germplasm to asses its correlation with resistance to biotic stresses. If this correlation exists then it will be possible to use epidermal PPO-quantitativeanalysis as a marker for selecting resistant alfalfa genotypes.

Acknowledgement: Thanks are due to Mr A. Bolletta for his excellent technical assistance.

\section{REFERENCES}

[1] Bouthyette P.Y., Eannetta N., Hannigan K.J., Gregory P., Solanum berthaultii trichomes contain unique polyphenoloxidases and a peroxidase, Phytochemistry 11 (1987) 2949-2954.

[2] Bradford M.M., A rapid and sensitive method for the quantitation of microgram quantities of protein utilizing the principle of protein-dye binding, Anal. Biochem. 12 (1976) 248-254.

[3] Cary J.W., Lax A.L., Flurkey H.F., Cloning and characterization of cDNAs coding for Vicia faba polyphenol oxidase, Plant Mol. Biol. 20 (1992) 245-253.

[4] Danielson S.D., Manglitz G.R., Sorensen E.L., Development of alfalfa weevil (Coleoptera: Curculionidae) larvae when reared on perennial glandular-haired Medicago species in the greenhouse, Environ. Entomol. 15 (1986) 396-398.

[5] Danielson S.D., Manglitz G.R., Sorensen E.L., Resistance of perennial glandular-haired Medicago species to oviposition by alfalfa weevils (Coleoptera: Curculionidae), Environ. Entomol. 16 (1987) 195-197.

[6] Duffy S., Felton G., Enzymatic antinutritive defenses of the tomato plant against insects, in: Hedin P. (Ed.), Naturally Occurring Pest Bioregulators, American Chemical Society, Washington, DC, 1991, pp. 166-197.

[7] Esterbauer H., Schwarzl E., Hayn M., A rapid assay for catechol oxidase and laccase using 2-nitro-5thiobenzoic acid, Anal. Biochem. 77 (1977) 486- 494.

[8] Hedrick J.L., Smith A.J., Size and charge isomer separation and estimation of molecular weights of proteins by disc gel electrophoresis, Arch. Biochem. Biophys. 126 (1968) 155-164.

[9] Hunt M.D., Eannetta N.T., Yu H., Newman S.M., Steffens J.C., cDNA cloning and expression of potato polyphenol oxidase, Plant Mol. Biol. 21 (1993) 59-68.
[10] Jiang Y., Miles P.W., Responses of a compatible lucerne variety to attack by spotted alfalfa aphid: changes in the redox balance in affected tissues, Entomol. Exp. Appl. 67 (1993) 3, 263-274.

[11] Johnson K.J.R., Sorensen E.L., Horber E.K., Resistance of glandular-haired Medicago species to oviposition by alfalfa weevil (Hypera postica), J. Environ. Entomol. 9 (1980) 241-244.

[12] Kowalski S.P., Eannetta N.T., Hirzel A.T., Steffens J.C., Purification and characterization of polyphenol oxidase from glandular trichomes of Solanum berthaultii, Plant Physiol. 100 (1992) 677-684.

[13] Kreitner G.L., Sorensen E.L., Glandular secretory system of alfalfa species, Crop Sci. 19 (1979) 499-502.

[14] Lax A.R., Vaughn K.C., Templeton G.E., Nuclear inheritance of polyphenol oxiase in Nicotiana, $\mathbf{J}$. Hered. 75 (1984) 285-287.

[15] Mathew A.G., Parpia H.A.B., Food browning as a polyphenol reaction, Adv. Food Res. 19 (1971) 75-145.

[16] Mayer A.M., Harel E., Polyphenol oxidases in plants, Phytochemistry 18 (1979) 193-215.

[17] Newman S.M., Eannetta N.T., Yu H., Prince J.P., de Vincente,. Tanksley S.D., Steffens J.C., Organisation of the tomato polyphenol oxidase gene family, Plant Mol. Biol. 21 (1993) 1035-1051.

[18] Pupilli F., Arcioni S., Damiani F., Protoplast fusion in the genus Medicago and isoenzyme analysis of parental and somatic hybrid cell lines, Plant Breed. 106 (1991) 122-131.

[19] Ryan J.D., Gregory P., Tingey W.M., Phenolic oxidase activities in glandular trichomes of Solanum berthaultii, Phytochemistry 21 (1982) 1885-1887.

[20] Sanchez-Ferrer A., Bru R., Cabanes J., GarciaCarmona F., Characterization of catecholase and cresolase activities of monastrell grape polyphenol oxidase, Phytochemistry 27 (1988) 319-321.

[21] Shade R.E., Thompson T.E., Campbell W.R., An alfalfa weevil larval resistance mechanism detected in Medicago, J. Econ. Entomol. 68 (1975) 399-404.

[22] Sherman T.D., Vaughn K.C., Duke S.O., A limited survey of the phylogenetic distribution of polyphenol oxidase, Phytochemistry 30 (1991) 2499.

[23] Sorensen E.L., Byers R.A., Horber E.K., Breeding for insect resistance, in: Hanson A.A., Barnes D.K., Hill R.R., Jr, (Eds.), Alfalfa and Alfalfa Improvement, ASA-CSSA-SSSA Publishers, Madison, Wisconsin, USA, 1988, pp. 859-901.

[24] Vaughn K.C., Lax A.R., Duke S.O., Polyphenol oxidase: the chloroplast oxidase with no established function, Plant Physiol. 72 (1988) 659-665.

[25] Yu H., Kowalski S.P., Steffens J.C., Comparison of polyphenol oxidase expression in glandular trichopmes of Solanum and Lycopersicon species, Plant Physiol. 100 (1992) 1885-1890. 